\title{
Research Paper: Mini Nutritional Assessment and its Correlation With Elderly Nursing Home Residents in Khorramabad, Iran
}

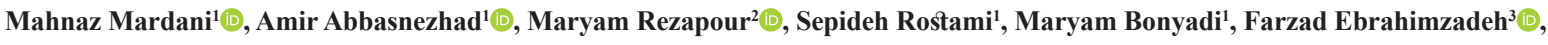
Razieh Choghakhori ${ }^{1^{*}(\mathbb{D})}$

1. Department of Health and Nutrition, Nutritional Health Research Center, Lorestan University of Medical Sciences, Khorramabad, Iran. 2. Department of Pharmacy, International Arvand Branch, Ahvaz Jundishapur University of Medical Sciences, Ahvaz, Iran.

3. Social Determinants of Health Research Center, Lorestan University of Medical Sciences, Khorramabad, Iran.

\begin{tabular}{|l|l|}
\hline $\begin{array}{c}\text { Use your device toscan } \\
\text { and read the article online }\end{array}$ & $\begin{array}{l}\text { Cittation: Mardani M, Abbasnezhad A, Rezapour M, Rostami S, Bonyadi M, Ebrahimzadeh F, et al. Mini Nutritional Assess- } \\
\text { ment and its Correlation With Elderly Nursing Home Residents in Khorramabad, Iran. Iranian Rehabilitation Journal. 2018; } \\
\text { 16(2):177-184. http://dx.doi.org/10.32598/irj.16.2.177 }\end{array}$ \\
doi: $:$ http://dx.doi.org/10.32598/irj.16.2.177
\end{tabular}

Article info:

Received: 05 Jan 2018

Accepted: 15 Apr 2018

\section{Keywords:}

Mini nutritional assessment, Elderly, Malnutrition, Nursing home

\section{ABSTRACT}

Objectives: Elderly nursing homes residents are at an increased risk of malnutrition due to a variety of factors. We aimed at investigating the prevalence of malnutrition and its correlation with elderly subjects using Mini Nutritional Assessment (MNA) questionnaire.

Methods: This cross-sectional study was conducted on elderly individuals $(\mathrm{N}=56$; female $=28)$ dwelling in the Sedigh Nursing Home in Khorramabad, Iran, in 2015. Nutritional status was assessed using MNA, which consisted of anthropometric measurements, global assessment, dietary questionnaire and subjective assessment.

Results: The participants' mean age was $74.86(\mathrm{SD}= \pm 11.82)$ years. The mean MNA-score of the subjects was $19.46(\mathrm{SD}= \pm 3.23)$. The prevalence of malnutrition and at risk of malnutrition were $20 \%$ and $70 \%$, respectively. No significant difference $(\mathrm{P}>0.05)$ was observed between male and female, age subgroups, marital status, education levels and different cut-off points of the Body Mass Index (BMI), Mid-Arm Circumferences (MACs) and Calf Circumferences (CCs) regarding the nutritional status of subjects. Malnutrition and risk of malnutrition were observed significantly and more frequently in elderly who had weight loss greater than $3 \mathrm{~kg}$, took more than three prescription drugs per day and had low/moderate protein intake $(\mathrm{P}<0.05)$. The MNA-score was independently associated with age, weight, BMI, MACs, CCs and food intake during last 3 months $(\mathrm{P}<0.05)$.

Discussion: According to high prevalence of malnutrition and risk of malnutrition among the subjects, proper nutritional interventions are required. Longitudinal studies on elderly and primary prevention by lifestyle interventions according to the culture and habits of the region are recommended.

\section{* Corresponding Author:}

Razieh Choghakhori, MSc.

Address: Department of Health and Nutrition, Nutritional Health Research Center, Lorestan University of Medical Sciences, Khorramabad, Iran.

Tel: +98 (912) 8980693

E-mail: choghakhori_r@yahoo.com 


\section{Introduction}

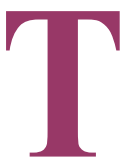

he number of older people around the world has shown an increasing trend in recent years [1]. Based on the report of Iran's Ministry of Health in 2005, the population of seniors who are 65 years and older accounted for $6 \%$ of the total population, and it is estimated that this rate will rise to $19 \%$ in 2030 [2]. Increasing elderly population is stated as one of the main challenges for health care system [1]. Nearly $50 \%$ of seniors over 65 years old have multi-morbidity, which is directly associated with aging, which also influences the needs of nursing homes [3]. Elderly in nursing homes are at an increased risk of malnutrition because of a variety of factors such as loss of appetite, eating disorders, decreased mobility, dementia, acute or chronic diseases and taking multiple medications [4]. The prevalence of malnutrition among the nursing home residents has a wide range in different populations. The results of the several studies assessing nutritional status among nursing home residents in Iran indicated that malnutrition is a major problem of these subjects, which needs more attention [4].

The use of biochemical markers is prolonged and costly, and the criteria for their interpretation in elderly people are unknown [5]. However, only a few community studies have been conducted in Iran to estimate the prevalence of malnutrition among seniors by using Mini Nutrition Assessment (MNA) questionnaire. MNA is an international questionnaire which is widely used in assessment of the nutritional state in aged people with high sensitivity, specificity, and diagnostic accuracy [6-8]. According to our knowledge, this study was the first of its kind in Khorramabad city of Iran. Therefore, we aimed to estimate the prevalence of malnutrition and correlation of nutrition status with related factors among elderly nursing home residents in Khorramabad, Iran.

\section{Methods}

\section{Study design and population}

This cross-sectional study was conducted on elderly individuals dwelling in the only nursing home (Sedigh Nursing Home) in Khorramabad, Iran, in 2017 (AprilJune). Samples were selected by simple random sampling method using the random number table. The sample size for the present study was calculated based on this equation [9]:
$N=Z^{2} S^{2} / d^{2}$

, where $\mathrm{Z}=1.96, \mathrm{~S}=3.0$ and $\mathrm{D}=1$.

Therefore, according to this formula, 34 subjects were estimated, which was multiplied by 1.5 due to the design effect. Finally, we recruited 56 subjects to compensate for any possible exclusion. The inclusion criteria were age of 60 years or over, living in nursing home for at least six months, without any hospitalizations for more than one week, signing an informed consent about participating in the study and ability to understand and answer the questions. The exclusion criteria were expired during the study and disapproving with participation in the study. This study was reviewed and approved by the ethics committee of the Lorestan University of Medical Sciences, Khorramabad, Iran (No. Ir.lums.rec.1396.302).

\section{Nutritional status}

Nutritional status was assessed with the MNA, a validated questionnaire for older individuals [8]. Clinical and population-based studies in geriatric patients showed that the MNA has a correlation with biochemical (albumin, pre-albumin, transferrin levels, and lymphocyte numbers) and anthropometrical markers (measuring of subcutaneous fat and mid arm circumference) [7]. This questionnaire was translated into Persian language and validated by the statistics experts [10]. The MNA questionnaire consisted of anthropometric indicators measurement (weight, height and weight loss), global assessment (lifestyle, medication and mobility), questionnaire regarding dietary intake (number of meals, food and fluid intake and autonomy of feeding) and subjective health status assessment (self-perception of health and nutrition) [11]. The MNA score $<17$ demonstrated malnutrition, the score of 17-23.5 demonstrated a risk of malnutrition, and the score $>24$ demonstrated well-nourished status [11].

\section{Anthropometric measurements}

Weight was recorded by a digital weighing machine to the nearest $0.1 \mathrm{~kg}$ and height was measured to the nearest $0.1 \mathrm{~cm}$ using astadiometer. The Body Mass Index (BMI) was defined as weight (in $\mathrm{kg}$ ) divided by height (in $\mathrm{m}$ ) squared. The Mid-Arm Circumference (MAC) was measured with a millimeter tape at the midpoint of the nondominant arm, between the olecranon and acromion. The Calf Circumference (CC) was measured by wrapping the tape around the widest part of the calf in a sitting position, left knee raised at a right angle, and the calf uncovered by rolling up the trouser leg. The BMI $<21 \mathrm{~kg} / \mathrm{m}^{2}$ 
indicated low BMI, MAC $<23.5 \mathrm{~cm}$ indicated low MAC and $\mathrm{CC}<30 \mathrm{~cm}$ indicated low $\mathrm{CC}$ [12].

\section{Statistical analysis}

All statistical analyses were carried out using the SPSS version 16 statistical software (SPSS Inc., Chicago, Ill). Kolmogorov-Smirnov test was used to evaluate the normality of the data distribution. We reported mean \pm SD for parametric data and median $\left(25^{\text {th }}, 75^{\text {th }}\right.$ percentile $)$ for non-parametric data. Independent t-test or Mann-Whitney U-test was used for comparisons between the male and female, when appropriate. Qualitative variables were compared between nutritional status categories using Chisquared test or Fisher's exact test. Binary logistic regression was used to examine the association between gender and MNA score. Moreover, Pearson correlation coefficient was used for determining the correlation between independent risk factors and MNA score. For all tests, two-sided $\mathrm{P}<0.05$ considered statistically significant.

\section{Results}

According to exclusion criteria, six subjects were initially excluded. So, this study was conducted on 50 elderly individuals, 22 (44\%) male and 28 (56\%) females. Most of the subjects were 80 years old and over $(\mathrm{N}=24)$. The mean MNA score was $19.46 \pm 3.23$. Table 1 shows that differences in baseline characteristics between male and female groups, which was statistically insignificant $(\mathrm{P}>0.05)$. The results of the MNA questionnaire showed that only $10 \%$ of the subjects were well nourished, and all of them were females (Table 2). Of the rest, $70 \%$ were at risk of malnutrition, and $20 \%$ were categorized as malnourished. There was no significant difference $(\mathrm{P}>0.05)$ between the male and female, age subgroups, marital status and education levels with respect to the nutritional status of the subjects (Table 2).

As can be seen in Table 3, we did not find any significant difference in nutrition status between different cutoff points of the BMI, MACs and CCs $(\mathrm{P}>0.05)$. Moreover, all the subjects who had BMI lower than 18.5 were malnourished or at risk of malnutrition (Table 3). As Table 4 demonstrates, malnutrition and risk of malnutrition are observed significantly and more frequently in elderly who have weight loss greater than $3 \mathrm{~kg}$, take more than 3 prescription drugs per day and have low/ moderate protein intake $(\mathrm{P}<0.05)$. Whereas the elderly subjects, who do not have any psychological stress or acute disease since the past 3 months, showed high frequency of malnutrition and risk of malnutrition $(\mathrm{P}<0.05)$. The results of the regression analysis of the data are presented in Table 5. The lower MNA-score was independently associated with higher age. Moreover, MNA-score had a significant positive correlation with weight, BMI, MACs, CCs and food intake during the last 3 months $(\mathrm{P}<0.05)$.

\section{Discussion}

We aimed at estimating the prevalence of different levels of malnutrition and related independent risk factors according to MNA, among the elderly nursing home residents in Khorramabad, Iran. To our knowledge, there were no studies conducted in Khorramabad, using the MNA questionnaire to assess the nutritional status. The MNA is a simple, noninvasive, and well-validated screening tool for early detection of malnutrition in elderly people $[8,13]$. The present study has shown that the prevalence of malnutrition was $20 \%$, near to the results obtained by Saha et al [14]. The value was $12.8 \%$ in another study by Afkhami [15] and $12 \%$ in the Aliabadi study [16], which was lower than our study. In Iran, the

Table 1. Baseline characteristics according to gender

\begin{tabular}{cccc}
\hline Variables & Male $(\mathbf{n}=\mathbf{2 2})$ & Female $(\mathbf{n}=\mathbf{2 8})$ & $\mathbf{P}$ \\
\hline Age $($ year $)$ & $74(63,84.25)$ & $79.5(66.25,83.75)$ & 0.76 \\
\hline Wt $(\mathrm{kg})$ & $56.75(50.30,75)$ & $50(44,63.75)$ & 0.051 \\
BMI (kg/cm $)$ & $21.92(19.24,27.44)$ & $22.1(20,25.5)$ & 0.76 \\
MACs (cm) & $21(20.75,22.25)$ & $21.75(21,22)$ & 0.58 \\
\hline CCs (cm) & $31(29.75,31.25)$ & $31(30.75,31.25)$ & 0.71 \\
MNA score* & $19.18 \pm 2.86$ & $19.67 \pm 3.53$ & 0.59 \\
\hline
\end{tabular}

Data are expressed as median $\left(25^{\text {th }}, 75^{\text {th }}\right.$ percentiles $)$ and tested by Mann-Whitney U test.

Ilranian Rehabilitation Journal

* The data is shown as mean $\pm S D$, and analyzed by independent $\mathrm{t}$ test. $\mathrm{P}<0.05$ was considered statistically significant. 
Table 2. Baseline characteristics according to nutritional status

\begin{tabular}{|c|c|c|c|c|c|c|}
\hline & \multirow[b]{2}{*}{ Variables } & \multicolumn{4}{|c|}{ Nutritional Status } & \multirow[b]{2}{*}{$\mathbf{P}$} \\
\hline & & $\begin{array}{l}\text { Well Nourished } \\
n(\%)\end{array}$ & $\begin{array}{c}\text { At Risk of } \\
\text { Malnutrition } \\
\text { n (\%) }\end{array}$ & $\begin{array}{c}\text { Malnour- } \\
\text { ished } \\
\mathrm{n}(\%)\end{array}$ & $\begin{array}{l}\text { Total Resi- } \\
\text { dents } \\
\mathrm{N}=\mathbf{5 0}(\%)\end{array}$ & \\
\hline \multirow[b]{2}{*}{ Gender } & Male & $0(0)$ & $17(48.6)$ & $5(50)$ & $22(44)$ & \multirow[b]{2}{*}{0.13} \\
\hline & Female & $5(100)$ & 18(51.4) & $5(50)$ & $28(56)$ & \\
\hline \multirow{3}{*}{ Age } & $60-69$ & $2(40)$ & $6(17.1)$ & $3(30)$ & $11(22)$ & \multirow{3}{*}{0.53} \\
\hline & $70-79$ & $2(40)$ & $11(34.4)$ & $2(20)$ & $15(30)$ & \\
\hline & $\geq 80$ & $1(20)$ & $18(51.4)$ & $5(50)$ & $21(48)$ & \\
\hline \multirow[b]{2}{*}{ Marital status } & Single & $2(40)$ & $15(42.9)$ & $6(60)$ & $23(46)$ & \multirow[b]{2}{*}{0.66} \\
\hline & $\begin{array}{l}\text { Married or Widow/ } \\
\text { widower }\end{array}$ & $3(60)$ & $20(57.1)$ & $4(40)$ & $27(54)$ & \\
\hline \multirow{2}{*}{ Education } & Illiterate & $4(80)$ & $30(85.7)$ & $6(60)$ & $40(80)$ & \multirow{2}{*}{0.2} \\
\hline & Primary/Middle school & $1(20)$ & $5(14.3)$ & $4(40)$ & $10(20)$ & \\
\hline
\end{tabular}

Iranian Rehabilitation Journal

All data are shown as number (\%), and analyzed by chi square test. $\mathrm{P}<0.05$ was considered statistically significant.

results of several studies have indicated that malnutrition is more than $40 \%$, and it is often associated with functional impairment, disability and impaired health [16-18]. Thus, the prevalence of malnutrition among non-institutionalized and independently living elderly is generally low $[19,20]$. In contrast, since the elderly generally lives in the nursing home because of disability and their need for help or care, high prevalence rates of malnutrition could be expected more in this group.
The recent studies have reported that within $20 \%$ of nursing home residents had some form of malnutrition [21]. However, the definitions of malnutrition were various and the reported prevalence ranged from $1.5 \%$ to $66.5 \%$ [21]. According to the present study, the prevalence of malnutrition was higher among the males as compared to females; however, it was not significant. The relationship between gender differences and inappropriate nutritional status is complex and unknown [22].

Table 3. Anthropometry indicators according to nutritional status

\begin{tabular}{|c|c|c|c|c|c|c|}
\hline \multirow{2}{*}{\multicolumn{2}{|c|}{ Anthropometry Indicators }} & \multicolumn{4}{|c|}{ Nutritional Status } & \multirow[b]{2}{*}{$\mathbf{P}$} \\
\hline & & $\begin{array}{l}\text { Well-Nourished } \\
\text { n (\%) }\end{array}$ & $\begin{array}{c}\text { At Risk of Malnutrition } \\
\qquad n(\%)\end{array}$ & $\begin{array}{c}\text { Malnourished } \\
n(\%)\end{array}$ & $\begin{array}{l}\text { Total Residents } \\
n=50(\%)\end{array}$ & \\
\hline \multirow{4}{*}{ BMI } & $<19$ & 0 & $4(11.4)$ & $2(20)$ & $6(12)$ & \multirow{4}{*}{0.23} \\
\hline & 19 to less than 21 & 0 & $8(22.9)$ & $3(30)$ & $11(22)$ & \\
\hline & 21 to less than 23 & 0 & $9(25.7)$ & $3(30)$ & $12(24)$ & \\
\hline & $23 \leq$ & $5(100)$ & $14(40)$ & $2(20)$ & $21(42)$ & \\
\hline \multirow{3}{*}{ MACs } & $<21$ & 0 & $7(20)$ & $2(20)$ & $9(18)$ & \multirow{3}{*}{0.28} \\
\hline & $21-22$ & $5(100)$ & $20(57.1)$ & $8(80)$ & $33(66)$ & \\
\hline & $22 \leq$ & 0 & $8(22.9)$ & 0 & $8(16)$ & \\
\hline \multirow[b]{2}{*}{ CCs } & Normal >31 cm & 0 & $10(28.6)$ & $3(30)$ & $13(26)$ & \multirow[b]{2}{*}{0.52} \\
\hline & Weak $31 \leq$ & $5(100)$ & $25(71.4)$ & $7(70)$ & $37(74)$ & \\
\hline
\end{tabular}

BMI: Body Mass Index; MACs: Mid-Arm Circumference; CCs: Calf Circumferences

All data are shown as number (\%), and analyzed by chi square test. P values $<0.05$ was considered statistically significant. 
Table 4. Health factors according to nutritional status

\begin{tabular}{|c|c|c|c|c|c|c|}
\hline & \multirow[b]{2}{*}{ Variables } & \multicolumn{4}{|c|}{ Nutritional Status } & \multirow[b]{2}{*}{$\mathbf{P}$} \\
\hline & & $\begin{array}{c}\text { Well- } \\
\text { Nourished } \\
\text { n (\%) }\end{array}$ & $\begin{array}{c}\text { At Risk of } \\
\text { Malnutrition } \\
\mathbf{n}(\%)\end{array}$ & $\begin{array}{c}\text { Malnourished } \\
n(\%)\end{array}$ & $\begin{array}{l}\text { Total Residents } \\
\quad n=50(\%)\end{array}$ & \\
\hline \multirow{3}{*}{$\begin{array}{l}\text { Food intake in last } \\
3 \text { months }\end{array}$} & A sharp reduction & 0 & $4(11.4)$ & $4(40)$ & $8(16)$ & \multirow{3}{*}{0.11} \\
\hline & A moderate reduction & $1(20)$ & $13(37.1)$ & $4(40)$ & $18(36)$ & \\
\hline & Without any reduction & $4(80)$ & $18(51.4)$ & $2(20)$ & $24(48)$ & \\
\hline \multirow{4}{*}{$\begin{array}{l}\text { Weight loss during } \\
\text { the last } 3 \text { months }\end{array}$} & No weight loss & 0 & 4(11.4) & 0 & $4(8)$ & \multirow{4}{*}{0.02} \\
\hline & $1-3 \mathrm{~kg}$ & 0 & $5(14.3)$ & $5(50)$ & $10(20)$ & \\
\hline & $3 \mathrm{~kg}<$ & 0 & $12(34.3)$ & $4(40)$ & $16(32)$ & \\
\hline & Does not know & $5(100)$ & $14(40)$ & $1(10)$ & $20(40)$ & \\
\hline \multirow{3}{*}{ Mobility status } & Bed or chair bound & $1(20)$ & $9(25.7)$ & $4(40)$ & $14(28)$ & \multirow{3}{*}{0.27} \\
\hline & $\begin{array}{l}\text { Able to get out of bed / chair but } \\
\text { does not go out }\end{array}$ & 0 & $4(11.4)$ & $3(30)$ & $7(14)$ & \\
\hline & Goes out & $4(80)$ & $22(62.9)$ & $3(30)$ & $29(58)$ & \\
\hline \multirow{2}{*}{$\begin{array}{l}\text { Psychological stress } \\
\text { or acute disease in } \\
\text { the past } 3 \text { months }\end{array}$} & Yes & $1(20)$ & $5(14.3)$ & $6(60)$ & $12(24)$ & \multirow{2}{*}{0.01} \\
\hline & No & $4(80)$ & $30(85.7)$ & $4(40)$ & $38(76)$ & \\
\hline \multirow{3}{*}{$\begin{array}{l}\text { Neuropsychologi- } \\
\text { cal problems }\end{array}$} & Severe dementia or depression & 0 & $7(20)$ & $2(20)$ & $9(18)$ & \multirow{3}{*}{0.66} \\
\hline & Mild dementia & $3(60)$ & $9(25.7)$ & $3(30)$ & $15(30)$ & \\
\hline & No psychological problems & $2(40)$ & 19(54.3) & $5(50)$ & $26(52)$ & \\
\hline \multirow{2}{*}{$\begin{array}{c}\text { Takes more than } 3 \\
\text { prescription drugs } \\
\text { per day }\end{array}$} & Yes & $3(60)$ & $20(57.1)$ & 10(100) & $33(66)$ & \multirow{2}{*}{0.02} \\
\hline & No & $2(40)$ & $15(42.9)$ & 0 & $17(345)$ & \\
\hline \multirow{2}{*}{$\begin{array}{l}\text { Pressure sores or } \\
\text { skin ulcers }\end{array}$} & Yes & 0 & $5(14.3)$ & 0 & $5(10)$ & \multirow{2}{*}{0.59} \\
\hline & No & $5(100)$ & $30(85.7)$ & 10(100) & $45(90)$ & \\
\hline \multirow{2}{*}{ Protein intake } & Low/ moderate intake & 0 & $21(60)$ & $6(60)$ & $27(54)$ & \multirow[b]{2}{*}{0.04} \\
\hline & Adequate intake & $5(100)$ & $14(40)$ & $4(40)$ & $23(46)$ & \\
\hline \multirow{2}{*}{$\begin{array}{c}\text { Two or more } \\
\text { servings of fruit or } \\
\text { vegetables Per day }\end{array}$} & Yes & 0 & $7(20)$ & $4(40)$ & $11(22)$ & \multirow{2}{*}{0.21} \\
\hline & No & $5(100)$ & $28(80)$ & $6(60)$ & $39(78)$ & \\
\hline \multirow{3}{*}{ Fluid intake per day } & $<3$ cups & 0 & $5(14.3)$ & $1(10)$ & $6(12)$ & \multirow{3}{*}{0.88} \\
\hline & 3- 5 cups & $2(40)$ & $16(57.7)$ & $6(60)$ & $24(48)$ & \\
\hline & 5 cups $<$ & $3(60)$ & $14(40)$ & $3(30)$ & $20(40)$ & \\
\hline \multirow{3}{*}{ Mode of feeding } & Unable to eat without assistance & 0 & $3(8.6)$ & $3(30)$ & $6(12)$ & \multirow{3}{*}{0.25} \\
\hline & Self-fed with some difficulty & 0 & $6(17.1)$ & $2(20)$ & $8(16)$ & \\
\hline & Self-fed without any problem & $5(100)$ & $26(74.3)$ & $5(50)$ & $36(72)$ & \\
\hline
\end{tabular}




\begin{tabular}{|c|c|c|c|c|c|c|}
\hline & \multirow[b]{2}{*}{ Variables } & \multicolumn{4}{|c|}{ Nutritional Status } & \multirow[b]{2}{*}{$\mathbf{P}$} \\
\hline & & $\begin{array}{c}\text { Well- } \\
\text { Nourished } \\
\text { n (\%) }\end{array}$ & $\begin{array}{c}\text { At Risk of } \\
\text { Malnutrition } \\
\mathbf{n}(\%)\end{array}$ & $\begin{array}{c}\text { Malnourished } \\
\text { n (\%) }\end{array}$ & $\begin{array}{l}\text { Total Residents } \\
\quad n=50(\%)\end{array}$ & \\
\hline \multirow{3}{*}{$\begin{array}{l}\text { Self-view of nutri- } \\
\text { tional status }\end{array}$} & $\begin{array}{l}\text { Views self as being malnour- } \\
\text { ished }\end{array}$ & 0 & $7(20)$ & $3(30)$ & $10(20)$ & \multirow{3}{*}{0.11} \\
\hline & Is uncertain of nutritional state & $1(20)$ & $19(54.3)$ & $6(60)$ & $26(52)$ & \\
\hline & $\begin{array}{l}\text { Views self as having no nutri- } \\
\text { tional problem }\end{array}$ & $4(80)$ & $9(25.7)$ & $1(10)$ & $14(28)$ & \\
\hline \multirow{4}{*}{$\begin{array}{l}\text { Consider his / her } \\
\text { health status }\end{array}$} & Not as good & 0 & $10(28.6)$ & $5(50)$ & $15(30)$ & \multirow{4}{*}{0.46} \\
\hline & Does not know & $2(40)$ & $11(31.4)$ & $3(30)$ & $16(32)$ & \\
\hline & As good & $1(20)$ & $9(25.7)$ & $1(10)$ & $11(22)$ & \\
\hline & Better & $2(40)$ & $5(14.3)$ & $1(10)$ & $8(16)$ & \\
\hline
\end{tabular}

Iranian Rehabilitation Dournal

All data are shown as number (\%), and analyzed by chi square test. $\mathrm{P}<0.05$ was considered statistically significant.

As shown in Table 3, we did not find any significant difference in nutritional status between different cutoff points of the BMI, MACs and CCs. Moreover, all the subjects who had BMI lower than 18.5 were malnourished or at risk of malnutrition. A longitudinal aging study in Taiwan indicated that BMI, MAC, and CC were all associated with current functional ability for elderly adults $\geq 65$ years of age [23]. Also, they suggested that BMI can be used as a long-term predictor of functional decline in elderly Taiwanese adults $\geq 65$ years old, while CC was a good indicator of current functional ability [23]. However, these parameters have important limitations in practice. For example, an elderly patient can have a high BMI but at the same time may be exposed to malnutrition because of inadequate food intake due to an underlying disease such as hip fracture or dementia [11]. On the other hand, an individual could be thin with a low BMI but without malnutrition [11].
As Table 4 demonstrates, malnutrition and risk of malnutrition is observed significantly in elderly who have weight loss greater than $3 \mathrm{~kg}$, take more than 3 prescription drugs per day and are at low/ moderate protein intake $(\mathrm{P}<0.05)$. Similar results have been shown in some of the previous studies $[9,24]$. The MNA is the most useful tool in assessment of geriatric population those who had recent weight loss [11]. Weight loss due to decreased appetite is mainly caused by depression in the elderly [25]. It is important to identify the people who are at risk of malnutrition before making intense changes in weight or serum levels of albumin. These people are likely to have a low calorie intake that can be easily corrected by proper nutritional intervention [11].

Regarding the association between malnutrition and independent risk factors, our study has indicated that the lower MNA-score was independently associated with higher age. We agreed with Abdelrahman et al.,

Table 5. Correlation between independent risk factors and MNA score

\begin{tabular}{ccc}
\hline Factors & $\mathbf{R}$ & $\mathbf{P}$ \\
\hline Age & -0.305 & 0.031 \\
Wt & 0.493 & $<0.001$ \\
BMI & 0.491 & $<0.001$ \\
MACs & 0.385 & 0.011 \\
\hline CCs & 0.322 & 0.023 \\
\hline Food intake in last 3 months & 0.424 & 0.002 \\
\hline & & Iranian Rehabilitation Journal
\end{tabular}

Pearson correlation coefficient was used for determining the correlation between independent risk factors and MNA score. $\mathrm{P}<0.05$ was considered statistically significant. 
2014 [26] and Baweja et al., 2008 [27] who showed that with increasing age, the risk of malnutrition also increased. Also Sarah et al., 2005 [28] conducted a cross-sectional study with the aim to measure the effects of aging on nutritional status of the elderly people. Their results demonstrated a significant effect of age on the anthropometric indicators and the variables of nutritional biochemical assessment. They concluded that aging was independently correlated with poor nutritional status. It can be interpreted that aging can make elderly more dependent and with reduced mobility [29]. It can also expose them to various illnesses including hypertension, diabetes mellitus, ischemic heart disease, dementia, dental problems and eating disorders. Moreover, social isolation further aggravates the problem. In the present study, MNA-score had a significant positive correlation with weight, BMI, MACs, CCs and food intake during the last 3 months $(\mathrm{P}<0.05)$. Our findings are in line with the results of a cross-sectional study conducted by Soini $\mathrm{H}$ et al. in 2004 [9]. Moreover, Murphy et al (2000) indicated similar results, with the exception that BMI had the strongest predictive effect on the total score [24].

This study is limited by the cross-sectional nature of the data, which does not provide any indication of the direction of effect or causality.

\section{Conclusion}

According to the MNA results, $20 \%$ were categorized as malnourished, $70 \%$ were at risk of malnutrition and only $10 \%$ of the subjects were well nourished. We found that all the subjects who had BMI lower than 18.5 were malnourished or at risk of malnutrition, but this difference was not significant. Malnutrition and risk of malnutrition were observed significantly in elderly who had weight loss greater than $3 \mathrm{~kg}$, took more than 3 prescription drugs per day and had low/ moderate protein intake. The study showed that the lower MNA-score was independently associated with higher age. Moreover, MNA-score had a significant positive correlation with weight, BMI, MACs, CCs and food intake during the last 3 months. Longitudinal studies would complement the present study to determine causality and directional effect of the factors. A comprehensive review of the seniors of the city, including residents of nursing homes (public and private) and families, is recommended from various perspectives and providing the guidelines for their proper nutrition according to the culture and habits of the region. Public health policies should be directed towards this area with a focus on primary prevention by lifestyle interventions.

\section{Ethical Considerations}

\section{Compliance with ethical guidelines}

Ethical issues (Including plagiarism, informed consent, misconduct, data fabrication and/or falsification, double publication and/or submission, redundancy, etc.) have been completely observed by the authors.

\section{Funding}

There is high appreciation for all members of Nutritional Health Research Centre (Lorestan University of Medical Sciences, Khorramabad, Iran) who provided the funding of this study (No. Ir.lums.rec.1396.302).

\section{Conflict of interest}

The authors declare no conflict of interest.

\section{Acknowledgments}

We would like to thank all residents of the Sedigh nursing home, their relatives, manager and staff members, who participated in this study.

\section{References}

[1] World Health Organization. WHO global report on falls prevention in older age. Geneva: World Health Organization; 2008.

[2] Amir-Sadri A, Soleimani H. [Elderly phenomena and its outcomes in Iran (Persian)]. Sedaye Jomhooriy-e Eslami Iran. 2005; 11(65):67-77.

[3] Wolff JL, Starfield B, Anderson G. Prevalence, expenditures, and complications of multiple chronic conditions in the elderly. Archives of Internal Medicine. 2002; 162(20):2269-76. [DOI:10.1001/archinte.162.20.2269] [PMID]

[4] Nazemi L, Skoog I, Karlsson I, Hosseini S, Mohammadi MR, Hosseini M, et al. Malnutrition, prevalence and relation to some risk factors among elderly residents of nursing homes in Tehran, Iran. Iranian Journal of Public Health. 2015; 44(2):218. [PMID] [PMCID]

[5] Reuben DB, Greendale GA, Harrison GG. Nutrition screening in older persons. Journal of the American Geriatrics Society. 1995; 43(4):415-25. [DOI:10.1111/j.1532-5415.1995. tb05818.x] [PMID]

[6] Kaiser MJ, Bauer J, Ramsch C, Uter W, Guigoz Y, Cederholm $\mathrm{T}$, et al. Validation of the Mini Nutritional Assessment ShortForm (MNA®-SF): A practical tool for identification of nutritional status. The Journal of Nutrition, Health and Aging 2009; 13(9):782-88. [DOI:10.1007/s12603-009-0214-7] [PMID] 
[7] Guigoz Y, Vellas B, Garry PJ. Assessing the nutritional status of the elderly: The Mini Nutritional Assessment as part of the geriatric evaluation. Nutrition Reviews. 1996; 54(1):S59. [DOI:10.1111/j.1753-4887.1996.tb03793.x] [PMID]

[8] Green SM, Watson R. Nutritional screening and assessment tools for older adults: Literature review. Journal of Advanced Nursing. 2006; 54(4):477-90. [DOI:10.1111/j.13652648.2006.03841.x] [PMID]

[9] Soini H, Routasalo P, Lagström H. Characteristics of the Mini-Nutritional Assessment in elderly home-care patients. European Journal of Clinical Nutrition. 2004; 58(1):64. [DOI:10.1038/sj.ejcn.1601748] [PMID]

[10] Ghazi L, Fereshtehnejad S-M, Abbasi Fard S, Sadeghi M, Shahidi GA, Lökk J. Mini Nutritional Assessment (MNA) is rather a reliable and valid instrument to assess nutritional status in Iranian healthy adults and elderly with a chronic disease. Ecology of Food and Nutrition. 2015; 54(4):342-57. [DOI 10.1080/03670244.2014.994743] [PMID]

[11] Vellas B, Guigoz Y, Garry PJ, Nourhashemi F, Bennahum D, Lauque S, et al. The Mini Nutritional Assessment (MNA) and its use in grading the nutritional state of elderly patients. Nutrition. 1999; 15(2):116-22. [DOI:10.1016/S08999007(98)00171-3]

[12] Tsai AC, Chang TL. The effectiveness of BMI, calf circumference and mid-arm circumference in predicting subsequent mortality risk in elderly Taiwanese. British Journal of Nutrition. 2011; 105(02):275-81. [DOI:10.1017/S0007114510003429] [PMID]

[13] Gazzotti C, Arnaud-Battandier F, Parello M, Farine S, Seidel L, Albert A, et al. Prevention of malnutrition in older people during and after hospitalisation: Results from a randomised controlled clinical trial. Age Ageing. 2003; 32(3):32125. [DOI:10.1093/ageing/32.3.321] [PMID]

[14] Saha S, Basu A, Ghosh S, Saha AK, Banerjee U. Assessment of nutritional risk and its associated factors among elderly women of old age homes of South Suburban Kolkata, West Bengal, India. Journal of Clinical and Diagnostic Research. 2014; 8(2):118. [DOI:10.7860/JCDR/2014/8321.4024]

[15] Afkhami A, Keshavarz SA, Rahimi FA, Jazayeri SAA, Sadrzadeh $\mathrm{H}$. [Nutritional status and associated non-dietary factors in the elderly living in nursing homes of Tehran and Shemiranat, 2004 (Persian)]. Payesh. 2008; 7(3):211-7.

[16] Aliabadi M, Kimiagar M, Ghayour-Mobarhan M, Shakeri MT, Nematy M, llaty AA, et al. Prevalence of malnutrition in free living elderly people in Iran: a cross-sectional study. Asia Pacific Journal of Clinical Nutrition. 2008; 17(2):285-89. [PMID]

[17] Amirkalali B, Sharifi F, Fakhrzadeh H, Mirarefin M, Ghaderpanahi M, Larijani B. Evaluation of the mini nutritional assessment in the elderly, Tehran, Iran. Public Health Nutrition. 2010; 13(9):1373-9. [DOI:10.1017/S1368980010000303] [PMID]

[18] Nowroozi J, Mirgalili A, Bagheri KP. Study on nutrition status and urinary tract infection in elderly people at nursing home. Iranian Journal of Public Health. 2004; 33(3):36-9.

[19] De Groot C, Van Staveren W. Undernutrition in the European SENECA studies. Clinics in Geriatric Medicine. 2002; 18(4):699-708. [DOI:10.1016/S0749-0690(02)00043-5]
[20] Margetts B, Thompson R, Elia M, Jackson A. Prevalence of risk of undernutrition is associated with poor health status in older people in the UK. European Journal of Clinical Nutrition. 2003; 57(1):69-74. [DOI:10.1038/sj.ejcn.1601499] [PMID]

[21] Bell CL, Lee AS, Tamura BK. Malnutrition in the nursing home. Current Opinion in Clinical Nutrition \& Metabolic Care. 2015; 18(1):17-23. [DOI:10.1097/MCO.0000000000000130] [PMID]

[22] Castel H, Shahar D, Harman-Boehm I. Gender differences in factors associated with nutritional status of older medical patients. The Journal of the American College of Nutrition. 2006; 25(2):128-34. [DOI:10.1080/07315724.2006.10719523] [PMID]

[23] Tsai HJ, Chang FK. Associations between body mass index, mid-arm circumference, calf circumference, and functional ability over time in an elderly Taiwanese population. PloS one. 2017; 12(4):e0175062. [DOI:10.1371/journal. pone.0175062] [PMID] [PMCID]

[24] Murphy M, Brooks C, New S, Lumbers M. The use of the Mini-Nutritional Assessment (MNA) tool in elderly orthopaedic patients. European Journal of Clinical Nutrition. 2000; 54(7):555. [DOI:10.1038/sj.ejcn.1601055] [PMID]

[25] Morley JE. Anorexia of aging: physiologic and pathologic The American Journal of Clinical Nutrition. 1997; 66(4):76073. [DOI:10.1093/ajcn/66.4.760] [PMID]

[26] Abdelrahman H, Elawam A. Nutrition status in community dwelling older population in an Egyptian urban area JARCP The Journal of Aging Research \& Clinical Practice. 2014; 3(3):137-43.

[27] Baweja S, Agarwal H, Mathur A, Haldiya K, Mathur A. Assessment of nutritional status and related risk factors in community dwelling elderly in western Rajasthan. Journal of the Indian Academy of Geriatrics. 2008; 4(1):5-13.

[28] Forster S, Gariballa S. Age as a determinant of nutritional status: A cross sectional study. Nutrition Journal. 2005; 4(1):28. [DOI:10.1186/1475-2891-4-28] [PMID] [PMCID]

[29] Rosso AL, Taylor JA, Tabb LP, Michael YL. Mobility, disability, and social engagement in older adults. Journal of Aging and Health. 2013; 25(4):617-37. [DOI:10.1177/0898264313482489] [PMID] [PMCID] 